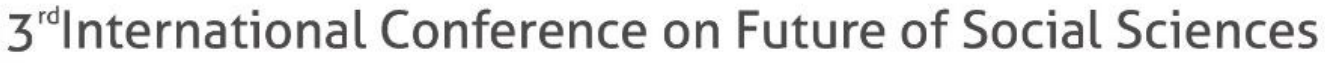

\section{The New Arbitration Law and Practice in UAE}

\author{
Dr. Sezin AKTEPE ARTIK \\ Altınbas University/ InShield Int. Consultancy, United Arab Emirates
}

\begin{abstract}
Arbitration is now a popular method of dispute resolution in the UAE and in the surrounding regions. Dubai in particular is considered a popular seat of arbitration in the region. This has been assisted by the presence of arbitration institutions such as the DIAC and the DIFC-LCIA Centre. The UAE Federal Arbitration Law (Law No:6 of 2018) was adopted in May and entered into force 30 days from its publication in the UAE Official Gazette on 16 June 2018. In the following paper we will examine, to what extent the newly adopted law is in part based on the UNCITRAL Model Law and in part customised to take account of local practice. In doing so, the present article compares the provisions of the new law with the UAE Arbitration Chapter and higlights the changes that may lead the local practice to the best practice in international arbitration.
\end{abstract}

Keywords: Dubai International Arbitration Center; Federal Arbitration Law; United Arab Emirates, Dubai, arbitration 